\title{
Impression Management Perempuan Perokok Di Kota Banda Aceh
}

\author{
Deni Yanuara*, Nur Anisah ${ }^{b}$, Maini Sartikac, Revita Rahman ${ }^{\mathrm{d}}$ \\ aUniversitas Syiah Kuala, Indonesia \\ bUniversitas Syiah Kuala, Indonesia \\ cUniversitas Syiah Kuala, Indonesia \\ dUniversitas Syiah Kuala, Indonesia \\ *deniyanuar@unsyiah.ac.id
}

\begin{abstract}
This study is entitled "impression management female smoker in Banda Aceh city". This study is describes how female smoker role to the society and people she meets. This study aimed to find out impression management female smoker, and to know frontstage and backstage female smoker of interacting with society in Banda Aceh city. Dramaturgy theory is used in this study. The approach used in this study is a qualitative descriptive method. The technique of determining informants used by researchers is purposive sampling technique. The research subjects are 3 informants who is female active smoker and stay in Banda Aceh city. The data collection techniques used are observation, interviews and documentation, By using interactive model analysis techniques, namely data reduction, data display, and making decisions. The result of the research shows that, female smoker plays a role to keep her identity as female smoker unknown by people like family, friends, and client. Although they often met with less pleasing views and behaviors in society, female smoker does not care about that thing. In impression management, there are some indicators that can be examined for how the female smoker's role is involved in her daily life, including, appearance, locution, friendships, and location. This study is expected to increas reference to next research. The study is also expected to make the public aware that not all girlseho smoke are bad women. And also alert female smokers that smoking is not good for their health and for others.
\end{abstract}

Keywords: Dramaturgy, Impression Management, Female Smoker.

\section{Latar Belakang}

Merokok merupakan suatu kegiatan yang dianggap sudah biasa dikalangan masyarakat di seluruh dunia untuk mengisi waktu senggang (Azanella, Ayu, 2018). Di Indonesia sendiri, pria perokok sudah dianggap wajar. Bahkan, di kota metropolitan seperti, Surabaya, Medan, dan Jakarta sekalipun jika ada perempuan yang menjadi perokok aktif, itu merupakan hal yang sudah wajar. Hal ini karena di kota-kota besar tersebut masyarakatnya cenderung heterogen sehingga tidak ada batasan bagi masyarakatnya mengekspresikan diri (Jamaludin, Nasrullah, 2017).

Setiap orang memiliki motivasi dan keinginan untuk mencapai suatu kepuasan. Namun, hanya sebagian saja yang menyesuaikan dan mengikuti ketentuan-ketentuan norma dan adat istiadat yang berlaku di setiap daerah dalam memenuhi kebutuhannya. Tipikal yang dianggap sebagian besar lingkungan tidak sesuai dengan norma dan ketentuan yang berlaku di setiap daerah dapat disebut dengan perilaku menyimpang. Perilaku menyimpang sendiri bukan serta merta melakukan tindak kejahatan, melainkan tindakan menyimpang kecil seperti pulang hingga larut malam, sarapan pakai tangan kiri, merokok yang dilakukan oleh wanita, dan perseteruan (Setiadi, M \& Kolip, 2018).

Penelitian sejenis sudah pernah dikaji sebelumnya dengan judul "Konsep Diri Mahasiswi Perokok (Studi Fenomenologi Konsep Diri Mahasiswi Perokok di Kota Banda Aceh)". Perbedaan dengan penelitian yang dilakukan ini terletak pada objek penelitian, di mana penelitian yang diteliti ini menggunakan segala bentuk interaksi komunikasi 
interpersonal, baik itu verbal maupun non-verbal antara perempuan perokok dengan teman yang baru dikenal dan teman dekat yang sudah lama dikenalnya. Selain itu(Rizkie, Fajrie, 2016), penelitian lain juga pernah dilakukan Sihombing yang berjudul "Impression Management Mahasiswi Perokok di Universitas Sumatera Utara (Studi Deskriptif Kualitatif Impression Management Mahasiswi Perokok di Universitas Sumatera Utara". Penelitian terdahulu juga memfokuskan subjek penelitian kepada mahasiswi yang sedang berkuliah di Universitas Sumatera Utara (Sihombing, Hagai, 2014). Namun, penelitian kami menggunakan subjek penelitian perempuan perokok dalam berbagai pekerjaan, baik mahasiswa, ibu rumah tangga, dan pekerjaan lainnya. Lokasi dalam melakukan penelitian juga berbeda. Selain itu, penelitian serupa juga pernah diteliti oleh Rizkina Putri R yang meneliti “Fenomena Perempuan Perokok di Pekanbaru”(Putri, 2016).

Di Aceh kental dengan syari'at Islam dengan masyarakat yang cenderung homogen, mungkin tidak salah jika masyarakat masih menganggap bahwa merokok bukanlah hal yang lazim dilakukan oleh perempuan. Hal tersebut dianggap melanggar norma-norma sosial dan budaya yang ada pada lingkungan masyarakat Aceh. Namun, berbeda dengan di kota-kota besar lainnya yang menganggap perempuan perokok menjadi hal yang biasa (Rosemary, 2018).

Menurut penuturan salah satu masyarakat Kota Banda Aceh, Cut Ruhul Afdar yang tinggal di daerah Darussalam selama 52 tahun, merokok tidak etis dilakukan oleh perempuan, walaupun saudara perempuannya juga ada yang merokok.

"Oh pernah, pernah ibu liat malah di keluarga ibu ada yang merokok emang.Ya sebenernya gak baikkan perempuan perokok itu. Kalau ibu nilai ya, kalau di Aceh itu rasanya gak sesuailah dengan syari'at islam yang di dengung-dengungkan di aceh ya. Kalau mungkin kalau di Jakarta itu mungkin ya kalau dikatakan emang sudah banyak masuk orang luar ya, udah masuk budaya-budaya orang, tapi kalau di Aceh ini karna kita tuntut syari'at Islam sebaiknya gak bolehlah merokok orang perempuan" (Afdar, 2019).

Seperti yang telah dijelaskan di atas bahwa Aceh mengandung syari'at Islam yang kental yang dibuktikan dengan adanya dasar undang-undang kerajaan sejak Sultan Iskandar Muda memimpin. (Bahri, 2013).

Ada beberapa pendapat ulama tentang rokok. Ada yang berpendapat bahwa merokok hukumnya tidak wajib, sunnah, makruh, mubah maupun haram (Kemenag, 2009) Seperti halnya Fatwa MPU yang mengharamkan rokok bila perilakunya mengganggu orang lain. Tidak jelas disebutkan hak siapa yang dilanggar atau tidak dihargai. Padahal cukup jelas para perokok, khususnya laki-laki, masih sangat terbiasa dan bebas hukum merokok di wilayah yang masuk kategori ruang umum. Ketika mereka merokok, masih sangat banyak hak-hak bukan perokok atau perokok pasif yang dilanggar, yakni para perempuan dan anak-anak yang berhak penuh menghirup udara bebas asap rokok di ruang publik tersebut (Rosemary, 2018). Kebiasaan merokok merupakan tindakan yang dapat membahayakan tubuh, tetapi terkadang, tidak sedikit masyarakat yang mengkonsumsinya, Bahkan kebanyakan awalnya hanya coba-coba kemudian menjadi ketagihan ketika dalam konsisi belia (Aulia,Ellizabet, 2010).

Menurut Soetjiningsih (2004), risiko dari mengkonsumsi rokok dapat menyebabkan batuk, asma, sinusitis, infeksi saluran napas bagian atas, penyakit kardiovaskular, kanker, mengganggu fertilitas, gangguan kehamilan dan janin bahkan sampai kematian. Walaupun risiko merokok yang tinggi dan bahkan peringatan merokok ada dicantumkan pada bungkus rokok, hal tersebut tidak membuat perempuan perokok 
takut untuk merokok. Hal ini bisa saja disebabkan karna merokok dapat menambah rasa percaya diri, kecakapan sosial, berani dan lain sebagainya.

Walaupun beberapa perempuan mengetahui bahaya dari rokok itu sendiri, mereka tetap masih merokok. Beberapa alasan populer untuk merokok adalah bahwa merokok dapat membuat diri santai dan terbebas dari berbagai masalah yang menyebabkan stress. Merokok inilah yang menjadi alasan untuk perempuan melepas stres yang bisa saja terjadi di rumah, kampus, maupun tempat kerja. Meskipun menurut mereka dengan merokok dapat menghilangkan stress dan dapat membuat diri lebih santai, tetap saja dampak negatif dari merokok lebih besar daripada manfaat yang dirasakannya (Slamet, 1993).

Menurut penelitian kesehatan dasar yang dimuat pada aceh.tribunnews.com (dalam Rosemary, 2018), "angka perokok wanita masih tergolong kecil (6,7\%) jika dibandingkan dengan laki-laki (65\%) memang belum menjadi ancaman kesehatan di Indonesia. Seperti di Kota Banda Aceh, perempuan yang merokok cuma 0,18\% dari 28\% laki-laki yang merokok. Jika dikalkulasikan dengan jumlah perempuan yang berada di Kota Banda Aceh yakni 122.128 orang, perempuan yang merokok masih dapat dihitung sejumlah 220 orang.

Qanun Nomor 5 Tahun 2016 tidak terealisasi dengan baik. Pasalnya, bukan hanya lelaki saja yang masih banyak merokok di sembarang tempat. Kini ada pula beberapa perempuan perokok yang secara terang-terangan merokok di tempat umum seperti di salah satu kafe yang bertempat di Lampineung. Menurut penuturan Juanda, seorang mahasiswa UIN Ar-Raniry ini pernah melihat secara langsung perempuan perokok di salah satu kafe di kawasan Lampineung tersebut. Perempuan perokok beserta beberapa temannya yang sedang kumpul di Cafe tersebut secara terang-terangan merokok.

"Pernah, pernah abang liat perempuan merokok. Pertama di Kepo (Café) yang di Lampineung $t u$, itu sering apalagi pas malam-malam minggu kan, sering abang duduk situ, ada yang merokok. Terus ada lagi di warkop dekat simpang BPKP tu gak tau nama warkopnya, gak terkenal-terkenal kalilah, agak-agak remangremang gitu, disitu ada(perempuan perokok)" (Juanda, 2019).

Lain halnya dengan salah satu informan yang seorang perempuan perokok juga, sebut saja namanya Bunga (nama samaran), dia merokok hanya di depan teman terdekatnya atau teman yang memang sudah lama menjalin pertemanan dengannya. Namun, di depan orang yang baru dikenalnya maupun masyarakat di sekitarnya, dia menutupi jika dia adalah seorang perempuan perokok. Hal ini disebabkan oleh kekhawatirannya kelak ia tidak diterima sebagai perempuan perokok untuk orang lain. Apalagi Aceh dikenal memiliki budaya Islami yang kental yang menganggap perempuan seharusnya menonjolkan sifat-sifat feminim seperti, kelembutan, kehalusan budi, dan lemah gemulai (Setiadi, M \& Kolip, 2018). Inilah yang membuat dirinya merasa kurang nyaman bila label perempuan perokok yang ada pada dirinya diketahui orang lain karena merokok merupakan kegiatan yang sering pria lakukan.

Tentu saja, pengaturan kesan sangat diperlukan perempuan perokok dalam berinteraksi dengan masyarakat. Perempuan perokok juga bermain peran yang baik secara frontstage maupun backstage. Interaksi yang dilakukan perempuan perokok dengan masyarakat satu dengan masyarakat lainnya akan berbeda. Menurut peneliti, melalui proses interaksi inilah perempuan perokok harus memikirkan peran apa yang harus mereka berikan kepada masyarakat yang tidak suka dengan adanya perempuan 
perokok tersebut. Dalam pengaturan kesan tersebut, frontstage maupun backstage yang dilakukan perempuan perokok tersebut juga pastinya akan berbeda.

Menurut Goffman dalam suatu perjumpaan masing-masing pihak secara sengaja maupun tidak sengaja membuat pernyataan (expression) pihak lain memperoleh kesan (impression). Goffman membedakan dua macam pernyataan, yaitu pernyataan yang diberikan (expression given) dan pernyataan yang dilepaskan (expression given off). Pernyataan yang diberikan merupakan pernyataan yang dimaksudkan untuk memberikan informasi sesuai dengan apa yang lazimnya berlaku. Pernyataan yang lepas atau dilepaskan, di pihak lain mengandung informasi yang menurut orang lain memperlihatkan ciri si pembuat pernyataan (Sunarto, 2004).

Pada penelitian sebelumnya, perempuan perokok akan berusaha mendesain dirinya dengan menggunakan penampilan, gaya bahasa, lokasi dan siapa orang yang akan melihatnya menjadi hal yang harus diperhatkan ketika berhadapan dengan publik. Maka dari itu, perempuan perokok mengatur kesan dan bermain peran agar tidak diketahui oleh masyarakat yang memandang buruk perempuan perokok. Lain halnya dengan masyarakat yang menerima akan kehadiran perempuan perokok maupun sesama teman perokok tersebut. Perempuan perokok tentu tidak akan sungkan untuk menunjukkan siapa dirinya. Hal inilah yang mendasari peneliti untuk mengetahui bagaimana peran yang dilakukan perempuan perokok dalam berinteraksi dengan masyarakat (Sihombing, Hagai, 2014).

Menurut Goffman, masalah utama yang dihadapi dalam berbagai hubungan sosialnya adalah mengontrol kesan-kesan yang diberikannya pada orang lain. Individu berusaha mengontrol penampilannya, keadaan fisiknya, di mana mereka memainkan peran-perannya serta perilaku perannya yang aktual dan gerak-isyarat yang menyertainya (Johnson, Paul, 1986). Margaret Paloma mendefinisikan dramaturgi sebagai pendekatan yang menggunakan bahasa dan khayalan teater untuk menggambarkan fakta subjektif dan objektif dari interaksi sosial (Paloma, 2003) .

Dalam teori dramaturgi, seseorang bermain peran dalam kehidupannya. Peran yang dilakukan seseorang kepada orang lain ini bertujuan untuk membina tingkah laku sosialnya guna memperlancar hubungan kehidupan bersama individu lain dalam keluarga, kelompok maupun masyarakat (Slamet, 1993). Menurut John dan Ruth Useem dalam Santoso (1993), peran adalah suatu pola atau tipe tingkah laku sosial yang cocok kepada individu sesuai dengan situasi, seseorang dituntut untuk tampil sebagaimana status atau situasi yang sedang disematkan padanya.

Pentas-depan adalah bagian atau tempat di mana saja audiens itu diharapkan ada, dan pelakon akan memberikan kesan baik atas dirinya kepada orang lain yang dianggap tidak dekat atau tidak sedang menjalin hubungan yang sangat baik dengannya(Narwoko,Dwi, 2015). Pentas-belakang merupakan tempat yang terlarang bagi audiens atau orang luar lainnya. Dalam pentas-belakang ini, pelakon bisa bersantai, pelakon tidak berurusan dengan penampilan atau kesan, dan pelakon menjadi diri sendiri tanpa harus berperan atau memberikan kesan baik kepada orang lain (Johnson, Paul, 1986).

Dalam West dan Turner (2008), komunikasi interpersonal merujuk pada pengiriman pesan yang terjadi secara langsung antara dua orang untuk membina dan mempertahankan hubungan maupun mencapai tujuan tertentu. Komunikasi interpersonal didefinisikan sebagai proses pengiriman dan penerimaan pesan-pesan 
antara dua orang atau sekelompok kecil orang-orang dengan beberapa efek dan beberapa umpan balik seketika (Soyomukti, 2011).

Menurut Verdeber dalam Budyatna dan Ganiem(2011), komunikasi antarpribadi adalah proses menciptakan dan mengelola hubungan mereka, melaksanakan tanggung jawab secara timbal balik dalam menciptakan makna. Ada pula ilmuwan lain yang mendefinisikan komunikasi antarpribadi adalah komunikasi yang terjadi antara orangorang secara bertatap muka, yang memungkinkan setiap khalayaknya menangkap reaksi orang lain secara langsung, baik secara verbal atau nonverbal (Mubarok,Andjani, dan Dwi, 2014).

Menurut Kleinjan dalam Bungin (2011), komunikasi sudah merupakan bagian kekal dari kehidupan manusia seperti halnya bernafas. Sepanjang manusia ingin hidup, maka ia perlu berkomunikasi. Dalam melakukan komunikasi, tentunya komunikator harus memperhatikan beberapa hal agar tidak terjadi kesalahpahaman dalam berkomunikasi. Apalagi bagi perempuan perokok yang tinggal di daerah yang memiliki syariat Islam yang kental harus memperhatikan diri ketika memulai komunikasi agar identitas diri sebagai perempuan perokok tidak diketahui orang lain. Komunikasi interpersonal yang terjalin akan berhasil ketika pesan yang ingin dituju dapat dipahami dan tercapai sesuai dengan apa yang kita maksud. Ketika seseorang yang tabu melihat perempuan perokok, pasti muncul anggapan bahwa perempuan perokok memiliki citra yang buruk dan bukan "wanita baik-baik". Namun, akan berbeda apabila berkomunikasi dengan seseorang yang menganggap perempuan merokok adalah hal yang biasa atau seseorang tersebut juga perempuan perokok,maka perempuan perokok tersebut tidak perlu menyembunyikan siapa dirinya.

Pada kenyataannya, peran yang harus dipentaskan seseorang biasanya relatif beragam. Orang-orang dalam hidupnya tidak mungkin hanya memerankan satu peran saja. Seseorang yang memerankan peran sosial tertentu tidak pada tempatnya, ia bukan saja akan dianggap aneh, tetapi bukan tidak mungkin ia juga akan ditertawakan atau dipergunjingkan (Narwoko dan Dwi, 2015).

Orang cenderung membentuk kesan atas orang lain berdasarkan informasi yang terbatas. Hanya dengan melihat seseorang selama beberapa menit saja, orang sudah cenderung menilai sebagian besar karakteristik orang tersebut. Meski biasanya individu tidak terlalu percaya pada pendapat yang dibentuk dengan cara demikian, mereka umumnya sudah menilai kepintaran, usia, latar belakang, ras, agama, tingkat pendidikan, kejujuran, kehangatan orang lain, dan sebagainya. Mereka juga menceritakan seberapa besar rasa suka mereka terhadap seseorang jika mereka telah mengenalnya lebih jauh (Sears, 2015).

Kehidupan sosial seperti berakting dalam suatu panggung teatrikal, dengan keseluruhan adegan, topeng, dan naskah di dalamnya. Peran-peran sosial memberikan kesempatan dan kebebasan menginterpretasi bagi mereka yang menjalankan peran tersebut. Namun, beberapa aspek dari setiap peran harus tetap ditampilkan (David, 2012). Interaksi sosial adalah proses di mana individu dengan individu, individu dengan kelompok, atau kelompok dengan kelompok lainnya berhubungan antara satu dengan yang lain. Ketika berinteraksi, seseorang atau kelompok sebenarnya tengah berusaha memahami tindakan sosial orang atau kelompok lain. Sebuah interaksi sosial akan kacau bilamana antara pihak-pihak yang berinteraksi tidak saling memahami motivasi dan makna tindakan sosial yang mereka lakukan. Menurut Mead, interaksi bisa berjalan dengan tertib dan teratur dan anggota masyarakat bisa berfungsi secara normal, maka yang diperlukan bukan hanya kemampuan untuk bertindak sesuai dengan konteks 
sosialnya, tetapi juga memerlukan kemampuan untuk menilai secara objektif perilaku kita sendiri dari sudut pandang orang lain (Narwoko,Dwi, 2015).

Kita memahami makna dan mendapatkan kesan dari berbagai tindakan orang lain, seringkali lebih sering bergantung kepada kesan kita terhadap tindakan mereka dibandingkan dengan perkataan-perkataan mereka. Ungkapan-ungkapan mimik wajah, isyarat, kualitas tindakan, dapat menunjukkan kepada perasaan yang lebih akurat daripada tindakan secara verbal. Ketika seseorang berbicara, maka ia juga berkomunikasi secara nonverbal dan kebanyakan kita juga mengikuti hal ini untuk mengecek keaslian kata-kata tersebut. Kita menggunakan bentuk arus komunikasi nonverbal untuk menguji perkataannya.

Dalam penampilan, para aktor cenderung membimbing diri mereka sendiri dengan apa yang mereka anggap sebagai nilai-nilai resmi dari masyarakat. Tentu saja hal ini melibatkan aktor dalam situasi di mana adanya konflik nilai menekan mereka untuk menguasai yang lainnya. Seorang aktor harus memahami suatu kenyataan bahwa berbagai kelompok dan situasi yang berbeda-beda itu menuntutnya untuk menunjukkan dirinya yang berbeda bagi setiap kelompok tersebut. Oleh sebab itu, untuk mempertahankan kesan yang sudah terbentuk, aktor tersebut berjuang untuk memisakan penontonnya sehingga ia mampu bermain dengan tepat untuk penonton yang tepat pula (Zeitlin, 1995)

Orang lain menilai kita sesuai dengan apa yang telah kita berikan melalui ekspresi, penampilan dan kesan. Dari penilaian tersebut akan tampak bagaimana orang lain memperlakukan kita. Jika kita memberikan kesan baik, maka baiklah perilaku orang lain terhadap kita dan begitupun sebaliknya. Untuk itu, kita secara sengaja menampilkan diri kita (self-presentation) seperti yang kita kehendaki (Rakhmat, 2008).

Menurut McRee dan Gebelt dalam Santrock (2005), merokok,di mana obat aktifnya adalah nikotin, adalah salah satu sumber utama timbulnya masalah kesehatan yang sebetulnya dapat dicegah. Rokok juga telah menjadi zat kimia yang paling sering digunakan dalam kehidupan sehari-hari oleh banyak kalangan. Secara khusus, kebiasaan merokok ini muncul karena kelompok teman sebaya yang merokok juga. Merokok menimbulkan beban kesehatan, sosial, ekonomi dan lingkungan, tidak hanya bagi perokok tetapi juga bagi orang lain. Produk tembakau adalah suatu produk yang secara keseluruhan atau sebagian terbuat dari daun tembakau sebagai bahan bakunya yang diolah untuk digunakan dengan cara dibakar, dihisap, dan dihirup atau dikunyah. Produk tembakau yang dimaksud mengandung zat adiktif dan bahan lainnya yang berbahaya bagi kesehatan baik secara langsung maupun tidak langsung (Menteri Kesehatan RI, 2013).

Perempuan yang seharusnya memiliki sifat lembut dan lemah gemulai, mungkin tidaklah keliru jika masyarakat menganggap perempuan perokok merupakan suatu hal yang tabu. Perempuan perokok mendapat penilaian negatif dari masyarakat karena perempuan perokok tidak sesuai dengan budaya yang telah ada pada masyarakat itu sendiri. Kebiasaan yang sering dilakoni kaum pria ini memiliki dampak negatif yang besar untuk perempuan. Dilansir pada Liputan6.com (Anas, 2016), ada beberapa alasan para wanita memilih menjadi perokok aktif yaitu untuk melampiaskan rasa stress, putus cinta, kebiasaan dari keluarga, merasa kesepian dan ikut-ikutan.

Berdasarkan penjelasan di atas, maka penelitian ini akan mendeskripsikan pengelolaan kesan perempuan perokok di kota Banda Aceh. 


\section{Metode Penelitian}

Lokasi penelitian ini dilakukan di wilayah Kota Banda Aceh. Alasan dipilihnya kota Banda Aceh sebagai lokasi penelitian adalah karena Aceh sendiri dijuluki sebagai kota "serambi mekkah" dan kota Banda Aceh sendiri memiliki Qanun Nomor 5 Tahun 2016 mengenai Kawasan Tanpa Rokok yang melarang kegiatan merokok. Qanun KTR ini mendukung Fatwa Majelis Permusyawaratan Ulama (MPU) Aceh Nomor 18 tahun 2014 tentang merokok Menurut Pandangan Islam yang menfatwakan rokok menjadi haram bagi mereka yang dilarang merokok secara medis dan bagi perokok yang tidak menghargai hak orang lain ini tidak terealisasikan dengan baik. Bahkan di kota Banda Aceh sendiri bukan hanya laki-laki saja yang merokok, tetapi juga ada perempuan. Penelitian ini tidak berfokus pada satu tempat saja. Data tetapi juga diambil di berbagai tempat di Kota Banda Aceh sesuai dengan kesepakatan antara peneliti dan informan.

Penelitian ini menggunakan pendekatan penelitian kualitatif dengan jenis Fenomenologi. Dalam penelitian ini, peneliti ingin menggambarkan dramaturgi dan impression management yang dilakukan perempuan perokok dalam berinteraksi dengan teman yang baru dekenal dan sudah lama dikenalnya. Penelitian ini difokuskan pada komunikasi interpersonal sehari-hari kepada teman yang dilakukan oleh perempuan perokok dalam berinteraksi baik dilakukan secara frontstage maupun backstage. Informan penelitian yang juga disebut sebagai subjek penelitian adalah orang pada latar penelitian yang dimanfaatkan untuk memberikan informasi tentang situasi dan kondisi latar penelitian (Moleong, 2019).

Dalam penelitian ini, yang menjadi informan penelitian adalah perempuan perokok di Kota Banda Aceh. Selain informan, ada objek penelitian yang akan diteliti. Objek penelitian adalah penjelasan tentang masalah apa yang akan diteliti, bisa juga ditambahkan hal-hal lain jika dianggap perlu (Umar, 2007). Objek penelitian dalam penelitian ini adalah segala bentuk interaksi komunikasi interpersonal baik verbal maupun non-verbal yang sudah termasuk frontstage dan backstage antara perempuan perokok dengan teman.

Teknik penarikan sampel yang peneliti gunakan adalah non-probability sample yaitu purposive sampling. Purposive sampling merupakan prosedur pemilihan siapa subjek yang ada dalam posisi terbaik untuk memberikan informasi yang dibutuhkan. Peneliti memilih subjek penelitian berdasarkan penilaian atas karakteristik anggota subjek yang dengannya diperoleh data yang sesuai dengan maksud peneliti (Ulber dan Gunarsa, 2009). Dalam penelitian ini, peneliti juga menetapkan kriteria untuk dijadikan informan, kriteria tersebut antara lain :

- Perempuan perokok aktif

Seseorang yang melakukan kegiatan merokok dan langsung menghisap rokok serta bisa mengakibatkan bahaya bagi kesehatan diri sendiri maupun lingkungan sekitar.

- Domisili di Kota Banda Aceh

Adapun daftar yang akan menjadi informan dalam penelitian ini adalah sebagai berikut.

Tabel 3.1 Daftar Nama Informan

\begin{tabular}{lll}
\hline No & Nama (Samaran) & Pekerjaan \\
\hline $\mathbf{1}$ & Bunga & Mahasiswa \\
\hline
\end{tabular}




\begin{tabular}{lll}
\hline $\mathbf{2}$ & Anggrek & Ibu Rumah Tangga \\
3 & Mawar & Penyiar Radio \\
\hline
\end{tabular}

Dalam penelitian kualitatif dikenal beberapa metode pengumpulan data yang umum digunakan, antara lain observasi, di mana peneliti akan mengamati segala bentuk komunikasi interpersonal yang di dalamnya mengenai pengaturan kesan, frontstage dan backstage ketika berhadapan dengan masyarakat. Observasi dilakukan di tempat yang terdapat perempuan perokok, seperti kafe, pantai, taman, kampus, dan lainnya.

Bentuk wawancara yang dilakukan menggunakan wawancara mendalam. Menurut Bungin (2011) wawancara mendalam merupakan proses memperoleh informasi dari pertanyaan-pertanyaan yang diajukan kepada informan secara tatap muka, dengan atau tanpa menggunakan pedoman wawancara, di mana pewawancara dan informan terlibat dalam kehidupan sosial yang relatif lama. Dokumentasi penelitian yang digunakan dapat berupa dokumen, aturan suatu lembaga (pemerintah), sistem yang diberlakukan, deskripsi wawancara, dan lain sebagainya. Proses penelitian kualitatif akan melibatkan data verbal yang banyak, yang harus dianalisis dari informan satu dengan informan lain yang sama atau bahkan berbeda. Dalam penelitian kualitatif, menurut Huberman dan Miles dalam (Idrus, 2009)mengajukan model analisis data yang disebut sebagi model interaktif. Model interaktif yang digunakan dalam penelitian ini ini terdiri dari 3 cara, yaitu: Reduksi Data penulis coding data-data yang relevan dari hasil wawancara dan obervasi kedalam hasil dan pembahasan kemudian melakukan Display Data dengan menyajikan data-data tersebut dan yang terakhir mengambil kesimpulan dan melakukan verifikasi tahapan tersebut juga dilakukan pengecekan keabshaan data menggunakan trianggulasi data.

\section{Hasil dan Pembahasan}

Peneliti mengumpulkan data yang berkaitan dengan impression management perempuan perokok di Kota Banda Aceh. Peneliti menggunakan pengumpulan data dengan menggunakan observasi, teknik wawancara dan dokumentasi. Data yang sudah diperoleh dari narasumber selanjutnya akan dikategorisasikan kedalam dua subbab pembahasan. Subbab pertama, penulis memaparkan gambaran umum penelitian dan subbab kedua peneliti akan membahas analisis dari hasil penelitian pada gambaran umum penelitian. Penelitian dilakukan terhadap tiga informan yang berdomisili di Kota Banda Aceh. Pekerjaan yang dilakoni informan dalam penelitian ini beragam, yakni mahasiswa, penyiar radio, dan ibu rumah tangga. Adapun dipilihnya mereka sebagai informan karena informan-informan tersebut sesuai dengan kriteria dalam penelitian ini.

Pada tahapan selanjutnya, peneliti menguraikan data yang telah didapatkan dan akan mengarahkan topik penelitian ke dalam bentuk makna perempuan perokok itu sendiri. Untuk memperoleh informasi secara mendalam, peneliti akan mengajukan beberapa pertanyaan yang diajukan secara acak.

Sebelum seseorang menjalani perilaku merokok secara rutin, tentu ada beberapa hal yang melatarbelakangi tindakan tersebut. Menurut penuturan dari Bunga, menyatakan bahwa:

"Awal mula merokok itu ya dari sekolah kelas 2 SMA, kira-kira tahun 2013-an gitulah awal mula merokoknya. Alasan merokok yaa broken home, yaa gara-gara keluarga gitu. Apa sih, ya terjadi-terjadi gitulah. Sebenernya, kalau alasan gara- 
gara broken home itu, broken home nya udah dari awal sih, dari SD kelas 5 itu sampe SMA tu masalahnya bertubi-tubi gitu dan aku itu tipe orang yang dibilang introvet kalipun engga ekstrovet kalipun enggak, ambivert lah, tengah-tengah. Tapi aku gak bisa menceritakan apa yang aku rasain itu ke orang lain. Dengan posisi aku anak tunggal gitukan. Ada masalah keluarga. Abis itu aku paling gaksukak kalo misalnya aku punya masalah cerita sama orang. Karna aku gak mau menambah beban pikiran orang itu sedangkan orang itu punya beban pemikiran lain di keluarganya sendiri. Jadi aku Cuma bisa memendam-memendam gitu, salah sih sebenarnya memendam itu, tapi cuma itu yang bisa kulakuin. Jadi puncaknya itu kelas 2 SMA tadi itu, udah gak tau lagi cerita ke siapa, yaa dengan orang-orang bilang merokok itu selo loh, ngerokok itu nanti ngilangin beban loh, apalah inilah itulah yang sebenarnya itu enggak. Abis tu cobak-cobak, awalnya emang seminggu sekali, atau memang kalau ada, kalo gak ada, yaudah sana gitu. Itulah satu-satunya jalan kalok aku punya dunia sendiri gitu" (Bunga, Wawancara, 29 Juli 2019)

Berbeda dengan Bunga, Anggrek menyatakan untuk pertama kali mengenal rokok bukan dari teman, melainkan anggota keluarganya sendiri yaitu neneknya. Anggrek mengatakan:

"Yaa... Mulai SMP bude udah merokok, tahun 80-an ya apa, ya gitulah. Dulu nenek bude kan merokok, jadi itulah ambil-ambil sebatang, dia kalo abis makan ngerokok, ikut-ikut, terus kebawak sampek sekarang, gak karna kawan tapi karna nenek" (Anggrek, Wawancara, 12 Oktober 2019)

Informan Mawar memiliki alasan tersendiri hal yang melatarbelakangi menjadi seorang perokok. Mawar mengaku hanya sekedar coba-coba dikarenakan temantemannya juga merupakan perokok. Dari hal coba-coba tersebut kemudian menjadi kebiasaan yang tidak bisa lepas dari kehidupan sehari-harinya. Mawar menyatakan:

"Awal mula mungkin kalo misalkan awal mula cobak-cobaknya itu selesai SMA, itu di fase coba-coba, ada temen ngerokok ikut ngerokok. Jadi aktifnya itu di tahun 2014, itu kebetulan kakak itu udah kerja, jadi event organizer, jadikan ngurusin event, jadi temen-temennya lingkungannya itu cowok semua. Jadi disitu mulai yang aktif merokok karna pertama, temen-temen perokok, yang kedua juga pekerjaannya kan pekerjaan laki-laki, jadi yang kayak kalo ngerokok ya enjoy aja. Ga ada alasan tertentu sih, karna udah jadi kebiasaan aja, dan itu adalah bagian dari hak asasi manusia aja, ya gak? Hahaha." (Mawar, Wawancara 4 Agustus 2019).

Selanjutnya peneliti menanyakan mengenai ada atau tidaknya orang-orang tertentu yang tahu bahwa mereka adalah seorang perokok. Bunga mengatakan:

"Kalo ngerokok tergantung kondisi sih, ada kawan-kawan yang memang perokok juga, enggak banyak sih, ada beberapa oranglah yang merokok juga. aku liat dari keseharian dia dulu, ada beberapa temen yang aku kasih tau. Tapi kalo disekitaran rumah itu memang gak ada yang tau. Tapi kalo kawan-kawan kampus itu ada, tapi itupun berdasarkan alasan aku liat dulu orangnya gimana. Ni misalnya ya, kalo dia ada masalah, terus cerita-cerita ke orang lain, itu tuh aku gak mau cerita sama orang-orang kayak gitu. Aku tuh cerita sama orang yang aku nyaman. Awalnya merekagak tau, tapi aku tu gak suka kalo mereka tutau dari orang lain, jadinya ya mending aku jujur sendiri, bilang sendiri aja gitubiar kasihtau."(Bunga, Wawancara 29 Juli 2019). 
Tidak jauh berbeda dengan Bunga, Anggrek awalnya merokok hanya diketahui oleh teman-teman sepermainannya saja hingga pada suatu hari, Anggrek kedapatan oleh adik kandung mamanya sedang merokok. Berikut pernyataan Anggrek:

"Awal-awal yang tau ya ibuk bude lah, tapi dia gak aduin takutlah dia bude di apain, tapi bude lah yang dimarahin. Cuma pernah juga bude ini pun ditangkep tangan bude, sama mamaknya bude, ini ditangkep (tangan) ini diambek (rokok) terus diginiin bibir bude (dimasukkan rokok), pernah, terakhir merokok lagi jugak. Hahaha. Cuma kalo lagi ngerokok diluar, pas lagi kumpul-kumpul sama kawan, pas ada orang yang lewat, ya agakdiumpet-umpetin jugaklah tapi kalo sama kawankawan, ya isap ajalah" (Anggrek, Wawancara, 12 Oktober 2019).

Berbeda halnya dengan Mawar, Mawar lebih leluasa melakukan kegiatan merokoknya, kecuali dengan klien kerjanya, berikut pernyataan Mawar:

"Sama sekali ga ada batasan, kecuali klien kerja kali ya, misalkan kakak lagi diluar Banda Aceh, entah di Aceh Besar, Bireun, Lhoksmawe, itu kan sering ada event-event gitukan, jadi kalo misalkan masuk kedalam lingkup yang baru, mungkin ketemu orang baru, yang ada hubungannya dengan kerjaan, itu kakak sejauh ini gitu aja, kayak pake jilbab tapi selendang dan tidak merokok. Tapi kalo misalkan kehidupan sehari-hari untuk kehidupan pribadi, ya ga ada hubungannya sama tabiat kakak ya engga pedulikan orang sih. Orang tua tau merokok, tapi tidak pernah merokok dirumah karna menghargai orang tua, rasanya anak laki-laki sekalipun mereka tetepkalo ada orang tua diem-diem ya merokok ga langsung depan orang tuanya, gitu" (Mawar, Wawancara 4 Agustus 2019).

Selanjutnya, peneliti menanyakan permasalahan respon orang-orang yang mengetahui atau melihat perempuan yang merokok. Berikut pernyataan Bunga:

"Ada dua versi ni, ada yang dia biasa aja, yaudah emang kenapa kalo merokok, kan gak ganggu kami gitu. Tapi ada juga yang, kayak terkejut gitu ada, abis tu nanyak ih kenapa kek gitu, sejak kapan gitu. Orang-orang kayak gitu akan muncul dengan pertanyaan yang gak kita duga-duga dia akan menanyakan kayak gitu. Terus ada lagi ni, versi ketiga, dia tu kayak munafik gitu ada, ih kok ke merokok, gak sayang diri ada, gak sayang tubuh ada. Itu tuh kayak suatu respon yang kayak mengecilkan kepribadian orang lain kayak gitu. Gimanaya bilangnya, ni kitakan manusia kan? Ga ada manusia yang ga ada salahnya, ga ada manusia yang dari lahir sampe mati itu buat baek aja gitu. Pasti bakal ada berbagai kesalahan,kesilapangitu dan berbagai macam perilaku yang gak sesuai dengan norma, etika, adat gitu kan, tapi, saat dia menge-judge orang dengan cara lebay dia ngomong kek gitu, kalo menurut aku itu seolah-olah aku salah banget apa sih? Sedangkan dia gak berkaca kepribadian dia kayak mana gitu. Perokok itu memang kalo di mata orang Aceh itu, merokok itu ih, salah ini itu bla bla bla, ya namanya Aceh, syariat Islam lah katanya entahapalah itu padahal didalamnya enggak jugak, tapi munafik gitu kan, di depan kita itukan, dengan jilbab dia yang panjang, ngomongnya yang bagus, di belakang kita dia yang lebih buruk gitu, itu yang aku gak sukak, gitu. Lebih baik ya to the point aja gitu" (Bunga, Wawancara 29 Juli 2019).

Tidak berbeda jauh dengan Bunga, Anggrek mendapatkan respon yang kurang baik, tetapi Anggrek tidak mau ambil pusing untuk menanggapinya. Anggrek menjelaskan:

"Ditengok gak etis, yaa ada sih ada pandangan jelek orang lain, tapikan bude orangnya cuek. Merokok aja bukannya mesti orang jahat, kan gitu. Cuma rasanya 
kayak mana ya kalo gak merokok, kayak kehilangan gitulah kalo gak merokok, kayak orang bingung, bude semakin ada rokok, semakin cepat kerjanya, makin rajin. Pas awal orang tua tau, ya ngamoklah, marahlah, marah besarpun, marah kali, sampai disuruh berhenti sekolah lah, apalah, suruh kerja, suruh carik uang sendiri" (Anggrek, Wawancara, 12 Oktober 2019).

Mawar juga mendapatkan respon yang kurang menyenangkan dari orang lain. Namun, respon keluarganya malah sebaliknya. Orang tua Mawar memberikan kebebasan untuk Mawar bisa berekspresi. Mawar menerangkan:

"Kebetulan dari keluarga papa kebanyakannya di Medan, jadi mereka biasa aja sih, cuma paling dibilang kamu kalo merokok diluar aja jangan dirumah entar banyak omongan tetangga, gitu aja sih. Banyak stigma negatif kalo misalkan perempuan perokok itu udah pasti dia bandel, suka keluar malam, gak bener, lain-lain itu udah hal yang paling sering dikeluarkanoleh masyarakat di Kota Banda Aceh, dibilang, sorry ya ini bahasanya kasar, ah cewek perokok itu perek dan segala macam, itu kayak yaudah ya itu menurut dia masing-masing, toh kita ga minta duit dia untuk ngerokok, kita juga tidak mau seperti itu, karna kitakan bicara soal hal-hal yang gitu gak harus perempuan perokok. Banyak juga yang psk-psk itu tapi jilbabnya panjang. Disini kakak paling sering kalo ngopi pagi, disitu sama temen-temen kadang ngerokok santai aja, ada yang ngeliatkayak misalnya bapak-bapak tu yang kayak dek-dek gitu, atau swit-swit, minta nomor HP dan lain-lain" (Mawar, Wawancara 4 Agustus 2019).

Peneliti melanjutkan wawancara dengan menanyakan tempat di mana biasanya mereka melakukan kegiatan merokok. Bunga menerangkan bahwa:

"Kalo di Cafe itu disini itu paling diruangan yang tertutuplah atau misalnya kalorame malem, carik yang dilantai 2 atau lantai 3 di cafe yang deketsimpang mesra situ, tapi gak sering sih, sekali dua kali aja. Kalo dirumah pas lagi sendirian aja. Paling sering itu diluar sih, ketimbang didalam ruangan gitu. Pernah juga tuh di lapangan, udah habis jogging-jogginggitu terus duduk-duduk, ya aku merokok disitu tapi aku duduk di antara para laki-laki yang semuanya ngerokok, jadi pas aku abis ngerokok, aku juga kasih ke mereka untuk ngerokok gitu" (Bunga, Wawancara 29 Juli 2019).

Tidak jauh berbeda dengan Bunga, Anggrek dulu melakukan kegiatan merokok bersama temannya. Namun setelah menikah, Anggrek lebih leluasa untuk merokok di rumahnya atau warung tempat ia berjualan.

"Diluar rumah. Yaa kumpul-kumpul sama kawanlah. Dulu budekan main-main volly, banyak laki-laki. Bebasnya dirumah ini setelah menikah lah" (Anggrek, Wawancara, 12 Oktober 2019).

Begitupun dengan Mawar yang biasanya merokok di beberapa warung kopi yang menurutnya moderen. Berikut pernyataan Mawar:

"Biasa di kalo kerjaannya banyak, di kantor, itu udah pasti ngerokok, di warkop yang warkop dalam tanda kutip modern, jadi kalo misalkan ngerokok di warkop Zakir, itu bunuh diri namanya, disitukan orang-orang yang awam, tapi kalo misalkan warkopwarkop yang sedikit modern ya orang-orangnya pikirannya terbuka, wawasannya juga terbuka yang dalam kutip hitslah, gaulgitu gak masalah sih, cuek aja. Kalo dirumah, di kamar sendiri, di balkon, di depan tv kalo lagi ga ada orang tua. Yaa liat situasi jugak sih. Kalo misalkan lagi masak di dapur ya lagi ngerokok, ngerokok aja 
gitu. Yaudah ga ada orang tua, ga ada orang dirumah" (Mawar, Wawancara 4 Agustus 2019).

Selanjutnya peneliti menanyakan bagaimana cara perempuan perokok untuk menata penampilan di depan publik. Berikut penjelasan dari Bunga:

"Kalo aku sendiri untuk lipstik atau apa itu engga sih, yaudah aja gitu, karna background aku dari kecil tu karna anak tunggal juga, dari kecil tu lebih condong ke laki-laki. Beli pakaian laki-laki atau apalah laki-laki semua laki-laki. Jadi kalo aku gak ber make-uppun ya mereka paham gitu. Kecuali ada hari-hari tertentu atau hari besar tertentu tu baru pake. Tapi kalo bau (rokok) sendiri tu, ya aku setiap abis ngerokoktu langsung kamar mandi, bersihin gitu kalo mau ketemu kawan ya pakai parfum gitu" (Bunga, Wawancara 29 Juli 2019).

Tidak berbeda dengan Bunga, Anggrek juga kurang peduli terhadap penampilannya dan biasa tidak mengenakan hijab. Anggrek menyampaikan bahwa:

"Emm.. ga ada kayaknya ya. Sama aja. Make-up pun budegak pakek. Pakaianpun biasa aja. Cuma ya itu, budegakpakek jilbab aja, dari dulu emanggitu. Walaupun udah pindah kemari. Kalaupun keluar-keluar paling pake selendang biasa aja gitu buat nutup kepala" (Anggrek, Wawancara, 12 Oktober 2019).

Begitu pula dengan Mawar, dalam kehidupan sehari-harinya dia tidak mengenakan hijab. Mawar cenderung mengenakan pakaian kaos lengan pendek dan tidak menggunakan hijab seutuhnya, hanya sebatas menutupi sebagian kepala dan terkadang tidak ditutupinya sama sekali saat keluar rumah. Berikut penuturan Mawar:

"Kakak memang, di Banda Aceh sendiri itu dari semenjak lahir dan sampai sekarang itu sampe besar memang bukan penganut syariat Islam yang terlalu bagaimana, jadi kalo masalah untuk pakaian ya sedikit terbukalah, gakpake jilbab, itu memang kebiasaaan yang terlepas dari kebiasaan merokok sih. Jadi kalo misalnya dikasih pilihan bukan perokok, ya kakak tetap ga pake jilbab dalam berpakaiannya pendek gitu" (Mawar, Wawancara 4 Agustus 2019).

Selanjutnya peneliti menanyakan sikap dan perilaku yang para perempuan perokok ini tampilkan di depan publik. Menurut penuturan Bunga, ia cenderung terbuka dengan teman yang dapat membuatnya nyaman. Namun, bila dengan keluarganya sendiri, dia akan menjadi cenderung tertutup. Berikut penjelasan Bunga:

"Aku orangnya, kalo aku udah kenal sama orang ni, aku kawanan, otomatis udah sayang dong sama kawan sendiri, kalo ada sesuatu yang menjanggal dari dia, aku ngomong gitu ke dia, apapun yang menyangkut dia gitu. Misalnya, dia ada hubungan asmara, ada hubungan dengan kawan-kawan dia yang enggak bagus, terus aku tu pasti menengahi itu karna aku ga sukak adanya pertengkaran, gimana caranya aku ngomong sama orang ni terus terang gitu untuk yaa jangan gitulah, kek gitukan. Pokoknya nanti kalo ada masalah aku menjadi penengah gitu ada, aku gak ikut campur sih, tapi jadi penengah gitu aja. Kalo sama keluarga itu fake, lebih ke menjaga image, gak mau kelihatan buruk-buruk kali tapi gak mau kelihatan yang baek kali pun, lebih tepatnya lebih menyesuaikan diri ke keluarga. Tapi kalo sama kawan-kawan itu yaudah, terbuka aja. Bahkan, kalo aku ni, kawan-kawan aku tu lebih paham aku ketimbang aku sendiri gitu. Kalo dari segi kesehatan, lebih kemana ya bilangnya, lebih ke batuk sih. Akhir-akhir ini, tiga bulan kebelakang ini tu memang batuk, parah, parah sekali. Sakit sampek ke kepala tu" (Bunga, Wawancara 29 Juli 2019). 
Anggrek pun demikian, keluarganya cenderung lebi tertutup daripada teman-temannya ketika sebelum menikah. Berikut penuturan Anggrek:

"Sama ajalah kayaknya. Kalo dirumah dulu ya jangan ngerokokaja, udah gitu jangan letak-letak rokok tu di kantong, ya kan nanti jatuh-jatuh pas mamakbude mau nyuci. Pande-pande lah. Tapi kalo sama kawan-kawan ya biasa aja. Ngerokok, ngerokok aja" (Anggrek, Wawancara, 12 Oktober 2019).

Berbeda jauh dengan Mawar, keluarganya cenderung lebih terbuka dan tidak mempermasalahkan jika Mawar adalah seorang perokok. Mawar mengatakan bahwa:

"Kalo sama keluarga itu sangat terbuka. Sama mama terbuka, sama papa terbuka. Karna kita dari kecil itu sekeluarga kami ada berlima, cewek semua, eh e abang udah meninggal, jadi kakak, aku anak kedua, sama ada dua adik, jadi kita dari kecil itu udah dididik sama orang tua untuk menjadi anak yang mandiri dan keras kepala. Kenapa? karna kitakan perempuan, jadi dibiasakan untuk bisa dari kecil jadi kita gak kaget besarnya" (Mawar, Wawancara 4 Agustus 2019).

Kemudian peneliti juga menanyakan tutur kata atau gaya bahasa yang perempuan perokok gunakan. Bunga mengatakan bahwa dirinya adalah seorang yang cenderung to the point jika mengatakan sesuatu kepada temannya. Namun, dirinya cenderung tertutup kepada keluarganya. Berikut penuturan Bunga:

"Dari dulu aku kalo ngomongnya memang blak-blakan orangnya, gak suka ngomong belakang-belakang, abis tu karna terdidik dengan kondisi keluarga yang keras akupun juga keras. Tapi kerasnya aku tu, kayak mana ya,nengok situasi dan kondisi jugak, misalnya kalo, oh orang ni bisa dibawa dengan cara keras berarti aku keras. Tapi kalo orang ni gak bisa dibawak dengan cara keras berarti aku harus lembut atau pelan gitu sama dia. Aku tu orangnya dari dulu emang gitu, kaloaku sukak ya aku bilang sukak gitu. Kalo enggak ya bilangnya enggak aja gitu. Aku itu orangnya gengsian, gengsinya gedek kali. Bahkan untuk ucapin maaf aja aku gak mau, bukan gak mau sih tapi kayak ah, apa sih. Aku mikir ya kan, kalo aku ucapin ini, pasti lucu ya kan, padahal itu enggak ya kan. Tapi di mindset sendiri udah tertanam kayak gitu. Paling kalo aku minta maaflewat chat, lewat wa, atau aku tulis di kertas gitu kan, aku tempel atau kalo gak aku tulis, aku sampein ke adek sepupu" (Bunga, Wawancara 29 Juli 2019).

Lain halnya dengan Anggrek, baik dengan kawan maupun keluarganya, dia tidak pernah berkata kasar. Berikut pernyataan Anggrek:

"Sama ajalah. Bude ngomong gak kasar, kami dalam keluargapun gak kasar kalo ngomong. Malah kalo ada yang ngomong kasar bude terkejut-kejut" (Anggrek, Wawancara, 12 Oktober 2019).

Berbeda pula dengan Mawar yang mengatakan bahwa tutur kata atau gaya bahasa tidak ada kaitannya dengan merokok. Menurutnya, merokok itu hanyalah suatu kebiasaan mengkonsumsi rokok dan tidak mempengaruhi yang lainnya. Mawar menjelaskan bahwa:

"Itu ga ada hubungannya kayaknya sama merokok dan gaya bahasa. Karna merokok itu adalah kebiasaan yang apa ya, kebiasaan mengkonsumsi rokok ni ceritanya, jadi terlepas kamu perokok atau kamu gak perokok gaya bahasa kayaknya gak ada hubungan gitu. Mungkin ada yang hijabers tidak merokok, tapi juga tidak menutup kemungkinan mereka berbahasa yang kurang santun, gitu" (Mawar, Wawancara 4 Agustus 2019). 
Dari temuan diatas dapat disimpulkan dramaturgi para narasumber sebagai berikut. Dalam kehidupan sehari-harinya, Bunga terkesan sebagai seseorang yang tertutup dan hanya menampilkan diri sebagai seorang perokok kepada teman yang membuatnya nyaman atau kepada orang-orang tertentu. Walaupun terkesan menutup diri, Bunga merupakan seseorang yang berbicara secara to the point. Saat ia suka dengan sesuatu, ia akan langsung mengatakan dan begitu pula sebaliknya. Bunga yang terbiasa tampil tomboi (seperti laki-laki) ini hanya menggunakan parfum sebagai senjata untuk menghilangkan bau rokok yang menempel di tubuhnya.

Tidak jauh berbeda dengan Anggrek yang memiliki pengalaman merokok yang lebih lama, pada masa mudanya dulu, Anggrek menutup dirinya sebagai seorang perokok kepada keluarganya. Mawar hanya menampilkan dirinya sebagai seorang perokok kepada teman-teman tertentu. Ibu rumah tangga yang berjualan makanan ini lebih leluasa merokok setelah menikah dikarenakan tidak adanya larangan baik dari keluarganya sendiri maupun dari suaminya. Walaupun tinggal di Kota Banda Aceh yang masyarakatnya menganggap hal yang tabu, kebiasaan merokoknya ini tetap berlanjut dan cenderung tidak peduli dengan apa yang dikatakan oleh orang lain.

Mawar merupakan salah satu informan yang dari awal memang bersifat terbuka. Baik dengan keluarganya sendiri maupun teman-temannya. Walaupun sering mendapat tatapan tidak suka dan gangguan tidak baik dari orang lain yang melihatnya sedang merokok, ia tetap tidak peduli dan hanya memberikan senyuman untuk balasannya. Mawar tidak menunjukkan dirinya sebagai seorang perokok kepada klien kerjanya karena menurutnya tidak semua klien kerjanya dapat menerima dirinya sebagai seorang perokok aktif. Hal ini pun dikhawatirkan dapat merusak hubungan kerjanya.

\section{Dramaturgi Perempuan Perokok}

Dari hasil wawancara yang telah dipaparkan pada pembahasan sebelumnya, peneliti dapat merangkum berbagai pernyataan dari para informan yang memberikan gambaran bagaimana dramaturgi dan impression management yang mereka lakukan sebagai seorang perempuan perokok dalam kehidupannya.

\section{Frontstage}

Dalam berinteraksi dengan orang lain, kita akan memberikan penilaian terhadap orang tersebut berdasarkan berbagai petunjuk yang orang lain tampilkan begitu juga sebaliknya. Berdasarkan penilaian itulah kita memperlakukan orang lain atau sebaliknya. Dengan kata lain, ketika kita berinteraksi dengan orang lain maka secara sengaja kita akan menampilkan diri kita sebagaimana yang kita inginkan. Kemudian, hal-hal yang dapat kita gunakan untuk menampilkan diri kita di hadapan orang lain disebut dengan front yang terdiri dari panggung, penampilan, dan gaya bertingkah-laku (Rakhmat, 2008).

\section{1) Bunga}

Bunga dalam kesehariannya berperilaku layaknya seorang wanita biasa. Biasanya, Bunga akan meng-cover dirinya dengan parfum agar tidak diketahui orang lain bahwa dirinya adalah seorang perokok. Bunga juga dalam berkomunikasi cenderung blakblakan orangnya. Dalam berpenampilan, bunga cenderung bersifat tomboi, tetapi tetap menggunakan hijab dalam kesehariannya walaupun sedang merokok ditempattempat tertentu seperti cafe-cafe yang tertutup.

2) Anggrek

Ketika awal mula mencoba merokok pada saat dirinya masih SMP, Anggrek memang diam-diam melakukan kegiatan merokok dan hanya teman-teman terdekatnya saja 
yang tahu bahwa dirinya adalah seorang perokok. Di depan teman-temannya, Anggrek lebih leluasa melakukan kegiatan merokok tersebut tanpa mempedulikan tatapan di sekitarnya. Namun setelah menikah, wanita yang berasal dari Medan ini tidak menyurutkan kegiatan merokoknya walaupun sudah pindah ke Kota Banda Aceh. Bahkan dirinya secara terang-terangan menunjukkan bahwa dirinya adalah seorang perokok, meskipun kegiatan merokoknya hanya dilakukan sekitar rumah dan ditempat ia berjualan.

3) Mawar

Mawar cenderung lebih terbuka baik keluarga maupun temannya tidak ada perbedaan. Dia tetap melakukan kegiatan merokok di beberapa tempat seperti kafekafe moderen yang menurutnya kafe tersebut berisi orang-orang yang memiliki pola pikir terbuka.

Ketika tahu Mawar adalah seorang perokok, keluarga Mawar hanya memberitahu Mawar untuk tidak merokok dirumah karena tidak enak bila dipandang oleh tetangga di sekitar rumahnya. Komunikasi yang dilakukan Mawar dan keluarganya sangat terbuka. Hal-hal yang terkait dirinya pasti akan diceritakan pada orang tuanya. Oleh sebab itu, orang tua Mawar mempercayakan sepenuhnya kepada Mawar karena Mawar dianggap sudah mengerti mana yang baik dan mana yang buruk untuk dirinya. Walaupun Mawar sering mendapatkan pandangan dan tindakan kurang menyenangkan dari orang lain ketika melihatnya sedang merokok, hal tersebut tidak menyurutkan dirinya untuk merokok dan mengungkapkan jati dirinya sebagai seorang perokok.

\section{Backstage}

Menurut Goffman, yang dimaksud dengan backstage adalah di mana penampil dapat melepaskan diri dari semua peralatan lengkap yang digunakan untuk menampilkan diri. Ketika pertunjukan telah selesai, individu kembali ke belakang panggung dan merasa lega bahwa berbagai tindakan yang ditampilkan di atas panggung telah secara bebas diekspresikan (Johnson, 1981: 45).

Semua tindakannya memang tidak akan memuaskan berbagai pihak, kecuali dirinya sendiri di belakang panggung. Belakang panggung adalah tempat di mana penampil hadir tanpa kehadiran khalayak yang menontonnya. Di belakang panggung pula, seorang penampil dapat keluar dari karakter aslinya tanpa merasa takut dapat merusak penampilannya.

1) Bunga

Bunga akan menunjukkan jati dirinya hanya kepada teman-teman yang dapat membuatnya nyaman. Dia tidak akan segan-segan melakukan kegiatan merokok terhadap temannya tersebut. Bunga memilih tempat-tempat tertentu untuk melakukan kegiatan merokoknya. Tempat tersebut antara lain kafe yang tertutup dan di rumah jika tidak ada orang lain.

2) Anggrek

Ketika masih SMP, hanya teman-teman sepermainan volly-nya saja yang tahu bahwa dirinya adalah seorang perokok. Anggrek akan lebih leluasa merokok bila sudah di luar rumah. Anggrek berusaha untuuk menutupi diri dari keluarganya.

Namun, ketika setelah menikah, Anggrek diberikan kebebasan dalam mengekpresikan dirinya sebagai seorang perokok. Pindah ke kota Banda Aceh yang memiliki syariat Islam tidak menyurutkan niat maupun tindakan Anggrek untuk merokok. Memiliki suami yang menerima bahwa dirinya adalah seorang perokok membuat dia lebih leluasa untuk merokok. Hanya saja, Anggrek merokok di perkarangan rumah dan di tempat ia berjualan makanan. 
3) Mawar

Mawar hanya menyembunyikan dirinya sebagai seorang perokok pada klien kerjanya. Mawar sadar bahwa tidak setiap orang dapat menerima perempuan merokok. Oleh sebab itu, Mawar biasanya tidak menunjukkan dirinya sebagai perokok kepada klien kerjanya.

Mawar memiliki kekhawatiran jika ia menunjukkan jati dirinya kepada klien kerjanya, hal itu dapat menurunkan rasa percaya dan nyaman klien kerjanya terhadap dirinya. Menurut Mawar, "Pertimbangannya kenapa gak merokok didepan klien karna itu akan mempengaruhi kalo kesan dia negatif sama kita otomatis dia ga akan beli produk kita, ga akan pakai jasa kita gitu. Ketika kita gak ada terikat kontrak kerjasama lagikan, yaudah ga apa-apa gitu". Oleh sebab itu, Mawar berusaha sebaik mungkin untuk menyembunyikan perilaku merokoknya ini kepada klien kerjanya.

\section{Pengelolaan Kesan}

Pengelolaan kesan tidak secara jelas berfokus pada teori, tetapi sebuah bentukan yang merepresentasikan suatu presentasi dan pengelolaan identitas sosial selama berlangsungnya proses interaksi. Pengelolaan kesan mengacu pada citra yang ditampilkan oleh seorang individu selama proses interaksi (Littlejohn dan Foss, 2012).

Berikut ini peneliti melampirkan masing-masing tabel impression management dari perempuan perokok yang telah diteliti sebagai pembeda antara informan satu dengan informan lainnya.

Tabel 4.1 Impression Management Bunga

\begin{tabular}{|c|c|c|c|}
\hline No. & $\begin{array}{c}\text { Impression } \\
\text { Management }\end{array}$ & Frontstage & Backstage \\
\hline 1. & Penampilan & $\begin{array}{l}\text { - Mengenakan gamis } \\
\text { beserta hijab } \\
\text { - Mengenakan Parfum }\end{array}$ & $\begin{array}{l}\text { Tomboi, lebih suka mengenakan baju } \\
\text { kaos, jaket dan celana namun tetap } \\
\text { mengenakan hijab. }\end{array}$ \\
\hline 2. & Gaya Bahasa & $\begin{array}{l}\text {-Menggunakan namanya } \\
\text { sebagai kata ganti } a k u \\
\text { - Menggunakan nama } \\
\text { lawan bicaranya atau } \\
\text { kamu }\end{array}$ & $\begin{array}{l}\text { Menggunakan sapaan hei, woy, aku, } \\
\text { kodalam berkomunikasi. }\end{array}$ \\
\hline 3. & Pertemanan & $\begin{array}{l}\text { - Keluarga } \\
\text { - Dosen } \\
\text { - Masyarakat }\end{array}$ & Teman dekat \\
\hline 4. & Lokasi & kafe-kafe tertutup & Rumah \\
\hline
\end{tabular}

Berdasarkan tabel di atas dapat dijelaskan bahwa impression management yang dilakukan oleh Bunga jika dilihat dari penampilan pada ranah fronstage, ia selalu menyesuaikan dengan penampilan wanita pada umumnya saat berada diluar rumah dan bertemu dengan orang-orang yang baru dikenalnya atau tidak akrab dengan dirinya. Sementara di area backstage, dia terkesan tomboi, lebih suka mengenakan celana dengan tetap mengenakan hijab saat bertemu dangan teman-teman akrabnya. Jika dilihat dari gaya bahasa saat bertemu dengan orang-orang yang dikenalnya, ia menggunakan namanya sebagai pengganti kata "aku" dan memanggil lawan bicaranya dengan kamu. Sedangkan pada area backstage, dia menggunakan saapaan, "hey", "woy", dan "aku" dalam 
berkomunikasi. Hal-hal yang dilakukan pada saat dia berada di frontstage biasanya dilakukan ketika menghadapi keluarga, dosen, dan masyarakat, dan area backstage hanya diperlihatkan pada teman dekat saja. Bunga juga membatasi lokasi-lokasi tertentu saja saat dia menampilkan sisi fronstage-nya, seperti di kafe-kafe tertutup atau di rumah.

Tabel 4.2 Impression Management Anggrek

\begin{tabular}{lcll}
\hline No. & $\begin{array}{c}\text { Impression } \\
\text { Management }\end{array}$ & \multicolumn{1}{c}{ Frontstage } & \multicolumn{1}{c}{ Backstage } \\
\hline 1. & Penampilan & $\begin{array}{l}\text {-Mengenakan baju kaos } \\
\text { atau kemeja beserta hijab } \\
\text { yang menutupi setengah } \\
\text { rambut }\end{array}$ & $\begin{array}{l}\text { - Lebih suka mengenakan baju kaos } \\
\text { dan celana } \\
\text { - Tidak mengenakan hijab }\end{array}$ \\
2. & Gaya Bahasa & Tutur kata lembut & Tutur kata Lembut \\
3. & Pertemanan & Keluarga & Teman-teman \\
4. & Lokasi & $\begin{array}{l}\text { Warung tempatia } \\
\text { berjualan }\end{array}$ & rumah \\
& &
\end{tabular}

Berdasarkan tabel di atas dapat dijelaskan bahwa impression management yang dilakukan oleh Angrek jika dilihat dari penampilan pada ranah frontstage, ia selalumengenakan baju kaos atau kemeja beserta hijab yang menutupi setengah rambut, sedangkan di area backstage lebih suka mengenakan baju kaos dan celana tanpa mengenakan hijab. Jika dilihat dari gaya bahasa, saat bertemu dengan orang-orang yang dikenal, ia menggunakan tutur kata lembut yang sama dengan saat menampilkan area backstage. Hal-hal yang dilakukan pada saat dia berada di frontstage biasanya dilakukan ketika hanya menghadapi keluarga saja dan area backstage hanya diperlihatkan pada teman. Angrek juga membatasi lokasi-lokasi tertentu saja jika dia ingin menampilkan sisi fronstage-nya, seperti di warung tempat ia berjualan, sedangkan sisi backstagenya ia tunjukkan saat di rumah.

Tabel 4.3 Impression Management Mawar

\begin{tabular}{lcll}
\hline No. & $\begin{array}{c}\text { Impression } \\
\text { Management }\end{array}$ & \multicolumn{1}{c}{ Frontstage } & \multicolumn{1}{c}{ Backstage } \\
\hline 1. & Penampilan & $\begin{array}{l}\text { - Tidak mengenakan hijab } \\
\text { - Mengenakan Parfum } \\
\text { - Mengenakan kemeja dan } \\
\text { rok } \\
\end{array}$ & $\begin{array}{l}\text { Mengenakan celana jeans dan baju } \\
\text { kaos }\end{array}$ \\
& & \\
& & \\
& Gengenakan Make-up & \\
2. & Gaya Bahasa & $\begin{array}{l}\text { Menggunakan bahasa } \\
\text { santun dan ramah }\end{array}$ & $\begin{array}{l}\text { Menggunakan bahasa santun dan } \\
\text { ramah. }\end{array}$
\end{tabular}

$\begin{array}{lll}3 . & \text { - Keluarga } & \\ & \text { - Klien } & \text { - Teman } \\ & & \text { - Rekan kerja }\end{array}$




\begin{tabular}{lll}
\hline 4. & Lokasi & $\begin{array}{l}\text {-kafe-kafe moderen } \\
\text {-Kantor }\end{array}$
\end{tabular}

Berdasarkan tabel diatas dapat dijelaskan bahwa impresion management yang dilakukan oleh Mawar jika dilihat dari penampilan pada ranah frontstage, ia selalu tidak mengenakan hijab, mengenakan parfum, kemeja, rok, dan make-up; sedangkan di area backstage ia lebih suka mengenakan celana jeans dan baju kaos. Jika dilihat dari gaya bahasa, saat bertemu dengan orang-orang yang ia kenal dia menggunakan bahasa santun dan ramah, sama halnya dengan saat di area backstage. Hal-hal yang dilakukan pada saat dia berada di frontstage biasanya dilakukan ketika sedang bersama dengan keluarga dan klien, dan area backstage hanya diperlihatkan pada teman dan rekan kerja. Mawar juga membatasi lokasi-lokasi di mana dia mengeluarkan sisi frontstage kafe-kafe modern dan kantor, sedangkan sisi backstage-nya ia tunjukkan di rumah.

\section{Kesimpulan}

Berdasarkan hasil penelitian yang telah dilakukan, peneliti dapat menarik kesimpulan bahwa perempuan perokok di Kota Banda Aceh tidaklah sedikit jumlahnya dan kebanyakan dari mereka lebih memilih untuk menutup diri karena khawatir adanya respon negatif dari masyarakat di sekitarnya. Hal ini dibuktikan adanya observasi dari peneliti dan survey dari Rosemary (2018)mengenai jumlah perokok perempuan yang semakin bertambah. Dari tiga informan yang telah diteliti, mereka juga sering mendapatkan pandangan dan tanggapan negatif dari orang-orang yang melihat mereka merokok, mereka cenderung tidak menanggapi dan tidak ambil pusing atas perlakuan negatif yang di dapat dari masyarakat. Dari ketiga informan tersebut memiliki keterbukaan diri yang berbeda-beda. Bunga lebih memilih terbuka pada orang-orang yang dapat membuatnya nyaman(expression given off). Dramaturgi bukan hanya mengenai frontstage dan backstage saja, namun impression management juga menjadi suatu topik yang menarik untuk diteliti. Dalam impression management, terdapat beberapa indikator yang bisa dilihat untuk diteliti bagaimana peran yang dijalani perempuan perokok dalam kesehariannya, yaitu penampilan, gaya bahasa, pertemanan dan pemilihan tempat..

\section{Referensi}

Anas, A. (2016). Kenapa Banyak Wanita Muda Memilih Jadi Perokok, Ini 5 Alasannya.

Retrieved March 2, 2021, from

https://www.liputan6.com/citizen6/read/2541329/kenapa-banyak-wanita-mudamemilih-jadi-perokok-ini-5-alasannya

Aulia,Ellizabet, lisa. (2010). STOP Merokok! (Sekarang atau Tidak Sama Sekali). (E. Syahriyanti, Ed.) (1st ed.). Yogyakarta.: Gara Ilmu.

Azanella, Ayu, L. (2018). Sejarah Rokok, dari Fungsi Medis hingga Jadi Candu Dunia. Retrieved from https://internasional.kompas.com/read/2018/05/31/13362751/sejarah-rokokdari-fungsi-medis-hingga-jadi-candu-dunia?page $=$ all

Bahri, S. (2013). Konsep Implementasi Syariat Islam di Aceh. Kanun - Jurnal Ilmu Hukum, 15(2), 313-338. https://doi.org/10.24815/kanun.v15i2.6174

Bungin, B. (2011). Penelitian Kualitatif: Komunikasi, Ekonomi, Kebijakan Publik, Dan Ilmu 
Sosial Lainnya. Kencana. https://doi.org/10.1002/jcc.21776

David, M. (2012). Psikologi Sosial. Jakarta: Salemba Humanika.

Ganiem, Mona, L., \& Budyatna, M. (2011). Teori Komunikasi Antarpribadi. Jakarta: Kencana $\begin{array}{llll}\text { Prenada Media } & \text { Group. } & \text { Retrieved }\end{array}$ https://scholar.google.co.id/scholar?oi=bibs\&cluster=4880051911066208320\&bt $\mathrm{nI}=1 \& \mathrm{hl}=\mathrm{en}$

Idrus, M. (2009). Metode Penelitian Ilmu Sosial, Pendekatan kualitatif dan Kuantitatif. Jakarta: Erlangga.

Jamaludin, Nasrullah, A. (2017). Sosiologi Perkotaan. (B. Saebani, Ahmad, Ed.), Pustaka Setia Bandung (2nd ed., Vol. 2). Bandung: Pustaka Setia. Retrieved from http://digilib.uinsgd.ac.id/3652/1/SOSIOLOGI PERKOTAAN.pdf

Johnson, Paul, D. (1986). Teori sosiologi klasik dan modern (2nd ed.). Jakarta: Gramedia Pustaka Utama. Retrieved from http://slims.unib.ac.id:80/index.php?p=show_detail\&id=23408

Kemenag. (2009). Fatwa MUI, Rokok Hukumnya Makruh dan Haram. Retrieved May 20, 2021, from https://www2.kemenag.go.id/berita/81811/fatwa-mui-rokokhukumnya-makruh-dan-haram

Lexy J. Moleong, D. M. A. (2019). Metodologi Penelitian Kualitatif (Edisi Revisi). PT. Remaja Rosda Karya. https://doi.org/10.1016/j.carbpol.2013.02.055

Littlejohn, S., \& Foss, K. (2012). Encyclopedia of Communication Theory. Encyclopedia of Communication Theory. https://doi.org/10.4135/9781412959384

Menteri Kesehatan RI. (2013). PMK no 28 Th 2013 tentang pencantuman Peringatan Kesehatan dan Infomasi Kesehatan Pada Kemasan Produk Tembakau. Jakarta. Retrieved from http://bprs.kemkes.go.id/

Mubarok, \& Andjani, Dwi, M. (2014). Komunikasi Antarpribadi Dalam Masyarakat MajemukKomunikasi Antarpribadi Dalam Masyarakat Majemuk. Makasar: Dapur Buku.

Narwoko,Dwi, J. (2015). SOSIOLOGI Teks Pengantar Dan Terapan. (B. Suyanto, Ed.) (8th ed.). Jakarta: Kencana Prenada Media Group. Retrieved from https://inlislite.kalselprov.go.id/opac/detail-opac?id=42372

Paloma, M. (2003). Sosiologi Kontenporer :Memahami kembali Sosiologi : kritik terhadap Sosiologi Kontemporer. Jakarta: Rajakrafind Persada.

R, Putri, R. (2016). Fenomena Perempuan Perokok Di Pekanbaru. JOM FISIP, 3(1). Retrieved from https://media.neliti.com/media/publications/33005-ID-fenomenaperempuan-perokok-di-pekanbaru.pdf

Rakhmat, J. (2008). Psikologi Komunikasi. Bandung: Remaja Rosdakarya.

Rizkie, Fajrie. (2016). Konsep Diri Mahasiswi Perokok (Studi : Fenomenologi Konsep Diri Mahasiswi Perokok Di Kota Banda Aceh). Syiah Kuala. Retrieved from 
https://etd.unsyiah.ac.id/baca/index.php?id=26757\&page=1

Rosemary, R. (2018). Perempuan dan Rokok. Retrieved March 1, 2021, from https://aceh.tribunnews.com/2018/05/31/perempuan-dan-rokok

Santrock, W. J. (2005). Adolescence. Boston: McGraw-Hill.

Sears, D. O. (2015). Psikologi Sosial (5th ed.). Jakarta: Airlangga.

Setiadi, M, E., \& Kolip, U. (2018). Pengantar sosiologi: pemahaman fakta dan gejala permasalahaan sosial: teori, applikasi dan pemecahannya. Jakarta: Prenada Media.

Sihombing, Hagai, J. (2014). Impression Management Mahasiswi Perokok di Universitas Sumatera Utara. Sumatera Utara. Retrieved from https://textid.123dok.com/document/7q0jrvz6-impression-management-mahasiswi-perokokdi-universitas-sumatera-utara-studi-deskriptif-kualitataif-impressionmanagement-mahasiswi-perokok-di-universitas-sumatera-utara.html

Slamet, S. (1993). Perilaku Remaja yang Berkaitan dengan Kebiasaan Merokok. Cermin Dunia Kedoktoran. Yogyakarta.

Soetjiningsih. (2004). Tumbuh Kembang Remaja dan Permasalahannya (1st ed.). Jakarta: Sagung Seto.

Soyomukti, N. (2011). Pengantar Sosiologi. Yogyakarta.: Ar-Ruzz Media. Retrieved from http://katalogarpusdaprovjateng.perpusnas.go.id/detail-opac?id=2087

Sunarto, K. (2004). Pengantar Sosiologi (Edisi Revisi) (Revisi). Jakarta: Lembaga Penerbit FEUI.

Turner, Lynn H, West, R. (2008). Pengantar Teori Komunikasi: Analisis dan Aplikasi (3rd ed.). Jakarta: Salemba Empat.

Ulber, S., \& Gunarsa, A. (2009). Metode penelitian sosial. Bandung: Refika Aditama.

Umar, H. (2007). Metode Penelitian untuk Skripsi dan Jenis Bisnis. Jakarta: PT Raja Grafindo Perkasa.

Zeitlin, I. M. (1995). Memahami kembali sosiologi: kritik terhadap teori sosiologi kontemporer=Rethinking sociology: a critique of contemporary theory. Yogyakarta: Gadjah Mada University Press. 